\title{
Contribution of Public e-Procurement to Sustainable Development Goals in Indonesia: Systematic Literature Review
}

\author{
Leny Marita ${ }^{a, b, *}$, Nurita Andrianic, Muhammad Alkirom Wildanc, Yahya Surya Winata ${ }^{c}$, \\ Muhammad Syarif ${ }^{c}$, Muhtadin Muhtadin ${ }^{d}$, Muhammad Azmi Alamsyah ${ }^{\mathrm{e}}$ \\ ${ }^{a}$ Sekretariat Daerah Kabupaten Bangkalan, Bangkalan 69162, Indonesia \\ ${ }^{b}$ Program Magister Manajemen, Universitas Trunojoyo Madura, Bangkalan, Indonesia \\ ${ }^{c}$ Fakultas Ekonomi dan Bisnis, Universitas Trunojoyo Madura, Bangkalan, Indonesia \\ ${ }^{d}$ Mechanical Engineering, Chung Yuan Christian University, Taoyuan City, Taiwan \\ ${ }^{e}$ Industrial and System Engineering, Chung Yuan Christian University, Taoyuan City, Taiwan
}

\begin{abstract}
A B S T R A C T
The Sustainable Development Goals have become the UN's global goals in the 2015 to 2030 time frame. To achieve these goals, Indonesia has designated a National Roadmap for Sustainable Development Goals in Presidential Regulation Number 59 of 2017. The Presidential Regulation serves as a guideline for Ministries or Agencies in National Actions Plans on Sustainable Development Goals in their respective domains. Including in the Public Procurement of Goods/Services has been fostered to increase sustainable procurement. This Systematic Literature Review has been looking for research evidence to reveal the contribution of e-procurement in the Sustainable Development Goals in Indonesia for the last decade. The evidence has been systematically collected by following the SLR protocol from the indexing Portal Garuda (Garba Rujukan Digital) specific for published articles in Indonesia. Meanwhile, the international research on sustainable procurement has been ongoing since 2001; the review here shows that there has not been much research on sustainable procurement in Indonesia. The results of this review offer a future research agenda for sustainable procurement in Indonesia.
\end{abstract}

Keywords: e-Procurement, New Research Agenda, SDGs, Sustainable Public Procurement, Systematic Review.

Article History

Received 10 October 21

Received in revised form 01 November 21

Accepted 12 December 21

\section{Introduction}

The World Commission on Environment and Development in 1987 formulated the Global Agenda for Change as an aggrandized to the 1972 Stockholm declaration. The global agenda for change is an urgent call by the United Nations General Assembly[1] to 1) Propose long-term strategies to achieve sustainable development in 2000 and beyond. 2) Recommend ways to protect the environment, rendered in the collaboration between countries at the stage of economic and social development and lead to shared goals and mutual support that foresee the interrelationships between people, resources, environment, and development. 3) Consider methods and means by which the international community can deal more effectively with environmental issues. 4) Help define shared perceptions of long-term environmental issues and the efforts needed to address protection and enforcement issues development of the environment successfully, the longterm agendas for action over the coming decades, and aspirational goals for the world community. Afterward, the commitment to the Millennium Development Goals (MDGs) marks a historic global movement in achieving a series of principal social priorities in the world. Commenced in the United Nations General Assembly in 2000, the MDGs established measurable and time-bound goals for 2000 to 2015[2] consisting of; 1) Eradicating extreme poverty and hunger. 2) Delivering universal primary education. 3) Promoting gender equality and empowering women. 4) Reducing child mortality. 5) Improve maternal health. 6) Contend HIV/AIDS, malaria, and other diseases. 7) Ensure environmental sustainability. And 8) forge a global partnership for development. The Millennium Development Goals are followed by the Sustainable Development Goals (SDGs) for 2015 to 2030, introduced at the 2015 UN General Assembly. Sustainable Development includes the so-called triple bottom line for human welfare: People, Planet, Profit. The world community recognizes that they have a common goal of combining economic development, environmental sustainability, and social society. Unlike the MDGs, the SDGs accommodate development problems comprehensively, both qualitatively and quantitatively, offering a target for the completion of each goal[3].

Indonesia hastened to respond to the global SDGs commitment by preparing the National Roadmap for Sustainable Development Goals on the legal basis of Presidential Regulation number 59 of 2017. Since Presidential

* Corresponding author.

E-mail address: lenymarita13@gmail.com 
Regulation Number 16 of 2018 (PerPres 16/2018 henceforth) concerning Government Procurement of Goods/Services, in the framework of The National Action Plan for the SDGs, the Government Goods/Services Procurement Policy Institute (LKPP) has also encouraged Sustainable Public Procurement. Previously, since Presidential Regulation of the Republic of Indonesia number 54 of 2010 (PerPres 54/2010 henceforth) regarding Government Procurement of Goods/Services, it is mandatory for Central Government Ministries, Central Government Agencies, Local Government Work Unit (SKPD), Institutions to use State Budget or Local Government Budget to carry out procurement of goods/services electronically for all or part of work packages starting in the 2012 fiscal year. In conducting the e-procurement of goods/services, The Central Government Ministries, Central Government Agencies, Local Government Work Unit, Institutions may establish Electronic Procurement Services (LPSE)[4]. LPSE has designed to implement the service system in the eprocurement of goods/services and facilitate the Procurement Officer in conducting the procurement of goods/services electronically in The Central Government Ministries, Central Government Agencies, Local Government Work Unit, Institutions. The establishment of LPSE has been mandated in Presidential Decree 54/2010 [5]. Afterward, PerPres 16/2018 was issued, revoking PrePres 54/2010 and its amendments. In PerPres 16/2018, the name of ULP (Procurement Service Unit) changed to UKPBJ (Goods/Services Procurement Work Unit). In PerPres 16/2018, it is also starting to be encouraged to maximize the use of green industrial products. The term green industrial products were changed to environmentally friendly products in PerPres 12/2021 regarding amendments to PerPres 16/2018. Sustainable Public Procurement (SPP) has encouraged to provide benefits not only for the government but also for the society and environment since this regulation. This Systematic Review is to find research gaps in the areas of concern to the author. UKPBJ development strategy in sustainable development, including the implementation of LPSE in it. To get reliable, traceable, and accountable review results, the author uses a Systematic Literature Review [6].

\section{Literature Review}

Systematic Literature Review conducts to synthesize meaningful knowledge from numerous previous studies on a research topic[7]. There are significant differences between SLR and traditional literature reviews. The objectives of the SLR are to: answer specific questions, reduce bias in the selection of scientific articles, and summarize them objectively[6]. Systematic Literature Review departs from an evidence-based approach by adopting a replicable, scientific and transparent process, which intends to minimize bias in literature search and selection[8], The aforementioned is what distinguishes it from traditional narrative review. The traditional reviews generally carry out prejudiced summaries based on articles consolidated using unofficial methods, resulting in fragmented and conceivably biased conclusions [9], [10]. Over the last few years, research in the management field has used this SLR methodology to provide a comprehensive understanding of business literature topics and guide future research agendas [11].

The SLR method formerly has been used by Enang, et al., [12] to identify the factors that influence the transformation of sustainable public services. They researched were to analyze the transformations that occurred during the period from 2010 to 2019 based on the evidence gathered using the SLR. Boon, et al., [13] used the SLR method to analyze the development of HR management systems over the last three decades and envision variable constructs for their further research. Mohungoo, et al., [14] in searching for a research gap, also conducted an SLR on the hurdles of implementing e-Procurement in South Africa. Similar to those studies, we conducted a Systematic Literature Review to find research gaps in public procurement of goods/services. To determine our future research agenda, the Research Questions (RQ) in our Systematic Literature Review are:

RQ1: What are the problems related to the implementation of LPSE in ULP/UKPBJ?

RQ2: What are research variables and methods used?

RQ3: What are the contribution of government procurement of goods and services to sustainable development in Indonesia?

\section{Table 1. PICOC Element.}

\begin{tabular}{ll}
\hline Population & $\begin{array}{l}\text { Procurement Service Unit (ULP) or } \\
\text { Goods/Services Procurement Work Unit (UKPBJ) throughout } \\
\text { Indonesia }\end{array}$ \\
$\begin{array}{ll}\text { Intervention } \\
\text { Comparison }\end{array}$ & $\begin{array}{l}\text { Thectronic Procurement Services (LPSE) } \\
\text { Outcomes }\end{array}$ \\
& Research problems of the administration of LPSE, \\
& Observed research variables, \\
& The research method used. \\
& Economic management \\
Context & Sustainable Development \\
\hline
\end{tabular}

\section{Research Method}

\subsection{Preparing the literature review}

Planning is the initial stage of a systematic review to guide the process of achieving the objectives of this review, i.e, looking for research gaps for future research agendas in the areas of concern to the authors [7], [11], particularly UKPBJ development strategies, including the implementation of LPSE in it. The literature review is guided by the research questions. The review analysis is the answer to the research question determined at this planning stage. A good research question remains measurable, relevant towards understanding the State of The Art of this UKPBJ development strategies research topic [6]. In the SLR, the formulation of research questions is on based the PICOC elements [15], [16], i.e (1) Population, the research target group. (2) Intervention, issues of interest to researchers. (3) Comparison, research aspects for comparison of Interventions. (4) Outcomes, the results of the intervention. (5) Context, setting the research environment. The PICOC elements for SLR shown in Table 1 were guiding this research.

\subsection{Constructing review protocol}

The SLR was conducted with a strict implementation protocol according to Table 2 to ensure an unbiased review of the authors' preferences. The source of data for exploring research articles was from the Garuda portal (Garba 
Rujukan Digital). We chose this database source because LPSE was sitespecific in Indonesia. And the Garuda portal did well-fitted to index research published in Indonesian journals. Article search and article collection were from March 29 to May 22, 2021, for all articles containing the keyword "LPSE" or "Layanan Pengadaan Secara Elektronik" or "ULP" or "Unit Layanan Pengadaan" or "Procurement Service Unit" or "UKPBJ" or "Unit Kerja Pengadaan Barang/Jasa" or "Goods/Services Procurement Work Unit". Article selecting was publications from 2010 to 2021. We chose this period considering PerPres 54/2010 began to make electronic procurement mandatory through the LPSE and the Sustainable Development Goals established since 2015 by the United Nations.

Table 2. Systematic literature review protocol.

\begin{tabular}{|c|c|c|}
\hline & SLR Protocol & Rationalization \\
\hline $\begin{array}{l}\text { Search } \\
\text { data } \\
\text { source }\end{array}$ & $\begin{array}{l}\text { Garuda portal (Garba } \\
\text { Rujukan Digital) }\end{array}$ & $\begin{array}{l}\text { The Garuda portal did well-fitted } \\
\text { to index research published in } \\
\text { Indonesian journals. } \\
\text { Additionally, LPSE has location- } \\
\text { specific in Indonesia. }\end{array}$ \\
\hline $\begin{array}{l}\text { Search } \\
\text { keywords }\end{array}$ & $\begin{array}{l}\text { "LPSE" or "Layanan } \\
\text { Pengadaan Secara } \\
\text { Elektronik" or } \\
\text { "ULP" or "Unit Layanan } \\
\text { Pengadaan" or } \\
\text { "Procurement Service } \\
\text { Unit" or "UKPBJ" or "Unit } \\
\text { Kerja Pengadaan } \\
\text { Barang/Jasa" or } \\
\text { "Goods/Services } \\
\text { Procurement Work Unit". }\end{array}$ & $\begin{array}{l}\text { Represent the population and } \\
\text { intervention elements of the } \\
\text { PICOC table. }\end{array}$ \\
\hline $\begin{array}{l}\text { Publication } \\
\text { period }\end{array}$ & $2010-2021$ & $\begin{array}{l}\text { Presidential Decree } 54 / 2010 \\
\text { began to require electronic } \\
\text { procurement by LPSE moreover } \\
\text { Sustainable Development Goals } \\
\text { set for the } 2015-2030 \text { timeframe } \\
\text { by the United Nations. }\end{array}$ \\
\hline $\begin{array}{l}\text { Inclusion } \\
\text { criteria }\end{array}$ & $\begin{array}{l}\text { Publication in Sinta } \\
\text { accredited journal }\end{array}$ & $\begin{array}{l}\text { Peer-Reviewed and articles are } \\
\text { of higher quality than non- } \\
\text { accredited journals publishers. }\end{array}$ \\
\hline $\begin{array}{l}\text { Exclusion } \\
\text { criteria }\end{array}$ & $\begin{array}{l}\text { Articles that focus only on } \\
\text { Legal, Political, } \\
\text { Information System aspects }\end{array}$ & $\begin{array}{l}\text { This review only focuses on the } \\
\text { contribution of management } \\
\text { economics, strategic } \\
\text { management, and HR } \\
\text { management. }\end{array}$ \\
\hline
\end{tabular}

\section{Result and Discussion}

\subsection{Identification and selection of relevant literature}

The article exploration according to the search protocol from Table 2 returned 72 articles (Figure 1). The author uses the Mendeley application to manage the collected article library. Furthermore, the selection of articles paper with inclusion criteria, articles published in Sinta accredited journals, and exclusion criteria articles paper focuses only on legal, political, or technical aspects of information systems. This criterion was because articles in Sinta's accredited journals have proceeded through the peerreviewed stage and the articles' papers are of higher quality than nonaccredited journals. Furthermore, this review only focuses on seeking the contributions of management economics, strategic management, human resource management, and sustainable development. The selection results corresponding to Table 2 covered 38 articles published in Sinta accredited journals. There were 34 articles omitted from the data set because they originated from unaccredited journals by Sinta (Figure 1). More reciting, 29 articles selected that contribute to the science of management economics (Table A1). There were nine articles' papers excluded based on the exclusion criteria in Table 3. The summary of the article selection process has shown in Figure 1. Furthermore, for data extraction purposes, code tagging was carried out, covering (1) research problems, (2) research variables, (3) research methods, (4) research contributions from 29 articles reviewed.

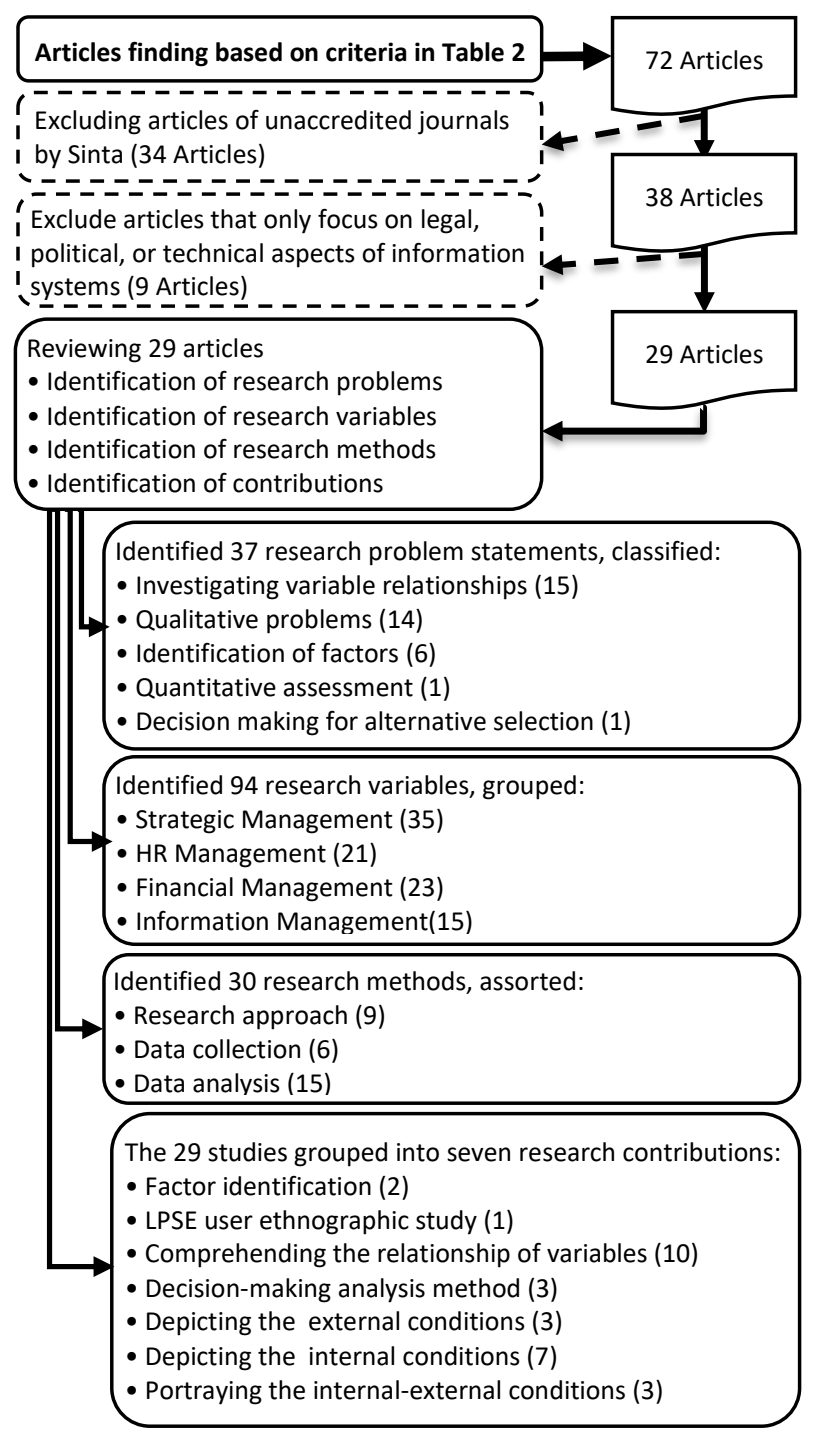

Figure 1. Systematic Literature Review Workflow 
Table 3. Identification of research queries in the category of qualitative problems.

\begin{tabular}{|c|c|c|c|}
\hline No. & Qualitative Problem & Authors & Tally \\
\hline 1. & $\begin{array}{l}\text { What was the significance of LPSE on } \\
\text { the procurement of goods/services? }\end{array}$ & {$[22]$} & 1 \\
\hline 2. & $\begin{array}{l}\text { How was the effectiveness and } \\
\text { efficiency of electronic procurement of } \\
\text { goods/services? }\end{array}$ & [22], [23], [24] & 3 \\
\hline 3. & $\begin{array}{l}\text { How to solve the intricacy of retentions } \\
\text { in the LPSE? }\end{array}$ & {$[22],[25]$} & 2 \\
\hline 4. & $\begin{array}{l}\text { How to apply the principle of e- } \\
\text { procurement to the ULP? }\end{array}$ & {$[25]$} & 1 \\
\hline 5. & What were the difficulties with LPSE? & {$[25]$} & 1 \\
\hline 6. & How was the LPSE accepted? & $\begin{array}{l}{[26],[27],} \\
{[24],[28],[29]}\end{array}$ & 5 \\
\hline 7. & $\begin{array}{l}\text { How was the transparency of the } \\
\text { LPSE? }\end{array}$ & [30], [31], [32] & 3 \\
\hline 8. & $\begin{array}{l}\text { How was the LPSE's internal control } \\
\text { system? }\end{array}$ & {$[33]$} & 1 \\
\hline 9. & $\begin{array}{l}\text { How to perform Probity Advice in } \\
\text { ULP? }\end{array}$ & {$[34]$} & 1 \\
\hline 10. & $\begin{array}{l}\text { What was the influence on budget } \\
\text { expenditure? }\end{array}$ & {$[23]$} & 1 \\
\hline 11. & $\begin{array}{l}\text { What was the role of the Decision- } \\
\text { maker Working Group (Pokja } \\
\text { Pemilihan)? }\end{array}$ & [35] & 1 \\
\hline 12. & $\begin{array}{l}\text { How was the quality of ULP services to } \\
\text { SKPD? }\end{array}$ & {$[28],[36]$} & 2 \\
\hline 13. & $\begin{array}{l}\text { How was the quality of ULP services to } \\
\text { business entities? }\end{array}$ & {$[28],[36]$} & 2 \\
\hline 14. & $\begin{array}{l}\text { Etc. Too technical to fit into the above } \\
\text { category }\end{array}$ & {$[18]$} & 1 \\
\hline
\end{tabular}

\subsection{Review of public procurement research problems}

Recapitulation of the tags code of the research problem from 29 articles obtained 38 research problem statements. We group these 38 problem statements into six categories: (1) Qualitative problems, (2) Finding relationship variables, (3) Identification of factors, (4) Quantitative assessment, (5) Qualitative assessment, (6) Alternative selection. Details of the identification of qualitative problems have presented in Table 3. The research variables investigated for their interaction relationships have present in Table 4. The factors of government procurement of goods/services examined, the quantitative assessment carried out, and alternative selection has presented in Table 5 .

The enactment of LPSE at ULP/UKPBJ since Presidential Decree $54 / 2010$ has encountered various problems identified in this review. In general, research problems be in the implementation of LPSE categorized into; qualitative research problems, investigating for variable relationships, factor identification problems, quantitative assessment problems, and alternative selection problems. The problem was ascertaining alternatives discussed by Arifin [17] in the decision-making of rent or purchase alternatives in the procurement of government official vehicles and Hamkah et al. [18] for the discerning of the type of public procurement contract. There are three quantitative assessment studies with the same objective, measuring the level of organizational maturity (Table 5). However, the three studies used different instruments. Mardiana and Cholil [19] used the ITIL V3 framework. Hulukati and Hikmawati [20] used the COBIT 5 framework. Darmapramita et al. [21] used the Indonesia Procurement Maturity Model (IPM2)

Table 4. Identification of research variables in the category of investigating variables relationship.

\begin{tabular}{|c|c|c|c|}
\hline No. & Variables & Authors & Tally \\
\hline 1. & accountability & [37], [38] & 2 \\
\hline 2. & efficiency & [37], [39] & 2 \\
\hline 3. & effectiveness & [37], [39] & 2 \\
\hline 4. & $\begin{array}{l}\text { transparency, strategy, } \\
\text { technology, organization, HR, } \\
\text { work environment }\end{array}$ & [37] & 1 \\
\hline 5. & coordination, discipline & [40] & 1 \\
\hline 6. & competence/proficiency & [40], [41] & 2 \\
\hline 7. & employee loyalty, leadership & [42] & 1 \\
\hline 8. & performance of employee & {$[42],[40]$} & 2 \\
\hline 9. & service quality & [42], [43], [28], [36] & 4 \\
\hline 10. & motivation & [43], [41] & 2 \\
\hline 11. & incentive & [41] & 1 \\
\hline 12. & organizational performance & [41], [28], [36] & 3 \\
\hline 13. & $\begin{array}{l}\text { employee responsibilities, } \\
\text { employee authority }\end{array}$ & [39] & 1 \\
\hline 14. & $\begin{array}{l}\text { LPSE implementation, market } \\
\text { access, business competition }\end{array}$ & [38] & 1 \\
\hline 15. & $\begin{array}{l}\text { construction cost, consulting cost, } \\
\text { goods expenditure, direct } \\
\text { expenditure }\end{array}$ & [44] & 1 \\
\hline
\end{tabular}

Table 5. Identification of research queries in the categories of factor identification, quantitative assessment, and alternative decision making.

\begin{tabular}{|c|c|c|c|}
\hline No. & Factor Identification & Authors & Tally \\
\hline 1. & $\begin{array}{l}\text { Factors restraining the } \\
\text { implementation of LPSE }\end{array}$ & {$[22]$} & 1 \\
\hline 2. & $\begin{array}{l}\text { Factors concerning the ULP } \\
\text { transparency }\end{array}$ & {$[30],[32]$} & 2 \\
\hline 3. & $\begin{array}{l}\text { Prevailing factor on the ULP service } \\
\text { quality }\end{array}$ & {$[42]$} & 1 \\
\hline 4. & LPSE encouraging factors & {$[35]$} & 1 \\
\hline 5. & LPSE hindering factor & {$[35]$} & 1 \\
\hline 6. & $\begin{array}{l}\text { Factors altering the maturity levels } \\
\text { of the ULP }\end{array}$ & {$[21]$} & 1 \\
\hline No. & Quantitative Assessment & Authors & Tally \\
\hline 1. & $\begin{array}{l}\text { Assessment of organizational } \\
\text { maturity level }\end{array}$ & [19], [20], [21] & 3 \\
\hline No. & Alternative Decision Making & Authors & Tally \\
\hline 1. & $\begin{array}{l}\text { Determination of procurement } \\
\text { scheme }\end{array}$ & {$[17],[45],[18]$} & 3 \\
\hline
\end{tabular}




\subsection{Review of public procurement research variables}

The recapitulation of the research variable tags code from 29 articles identified 94 research variables. We have arranged the 94 research variables into four categories: (1) Strategic Management, (2) HR Management, (3) Financial Management, (4) Information Management. Details of the identification of research variables have presented in Table B1. The research variables succeeding reviewed from 29 selected articles have presented in Table B1 by the assortment. Variables related to strategic management frequently studied are effectiveness, efficiency, ULP institutions, service quality, and procurement transparency. Variables related to HR management that are often studied are staff proficiency, workgroup performance, and incentives.

\subsection{Review of public procurement research methods}

Recapitulation of research methods on 29 articles' paper identified 30 research methods. The author groups these 30 research methods into three categories: (1) Research approach, (2) Data collection, (3) Data analysis. Details of the identification of research methods have presented in Table B2.

The qualitative problems identified in this study can have shown in Table 3. Most of them were solved using a qualitative research approach shown in Table B2. There were eight studies completed using qualitative research methods. However, not all qualitative problems in Table 3 are solved qualitatively, such as the service quality research by Budayasa et al. [36] also Sudiani et al. [28] were delivered by quantitative data analysis method using the Service Quality approach (Table B2).

The research queries of factor identification have presented in Table 5. The factor identification intends to describe the qualitative research from Table 3. The further analysis of Table B2 shows the research method for the description of factors in Table 5 [22], [30], [32], [35], [21]. were using descriptive-analytic [22], qualitative approach [30], [32], [35], and descriptive [21]. We did not find the use of quantitative methods such as the Statistical Factor Analysis method by the researcher in the factor identification.

The research queries looking for the relationship between variables have presented in Table 4. In reality, there are truly little quantitative data available in these variables, except for financial variables [44]. The quantification of these research variables in Table 4 generally uses a Likert scale questionnaire [28], [37], [39], [42] . Methods of data analysis to find the relationship of research variables using the analysis of the coefficient of determination [40], Partial Least Square [37], and eight other researchers using linear regression analysis [27], [28], [39]-[44] (Table B2).

\subsection{Review of public procurement research contributions}

The recapitulation of the tags code of research contributions from 29 articles grouped into seven domains (Table 6): (1) identification of factors, (2) ethnographic studies, (3) grasping the relationship of variables, (4) decision-making methods, (5) mapping of external conditions, (6) mapping of internal conditions, (7) mapping of internal-external conditions. An acquaintance of the actual relationship of government goods/services procurement variables contributes to managerial economics and HR management within UKPBJ. Portraying the internal and external conditions of LPSE and UKPBJ contributes to the strategic management of UKPBJ and LPSE development strategies.

Table 6. Identify research contributions.

\begin{tabular}{llll}
\hline No. & Contributions & Authors & Tally \\
\hline 1. & Factor identification & {$[30],[32]$} & 2 \\
2. & LPSE user ethnographic study & {$[24]$} & 1 \\
3. & $\begin{array}{l}\text { Comprehending the relationship } \\
\text { of variables }\end{array}$ & $\begin{array}{l}{[40],[37],[42],[43],} \\
{[41],[27],[39],[23],}\end{array}$ & 10 \\
& & {$[38],[44]$} & \\
& & {$[17],[45],[18]$} & 3 \\
4. & Decision-making analysis method & {$[26],[28],[36]$} & 3 \\
5. & Depicting the external conditions & {$[22],[25],[19],[46]$,} & 7 \\
6. & Depicting the internal conditions & {$[20],[21],[29]$} & \\
& & {$[33],[34],[35]$} & 3 \\
7. & Portraying the internal-external & & \\
& conditions & & \\
\hline
\end{tabular}

\subsection{Review discussion}

The dominant research queries in the administration of LPSE at ULP/UKPBJ based on the data findings in Table 3 to Table 5 were; (1) finding the relationship between variables and (2) qualitative research problems. For qualitative problems, what was widely studied is LPSE acceptance among business entities and Local Government Work Unit (SKPD) [24], [26]-[29]. In addition, the problems of transparency, effectiveness and efficiency of LPSE are also frequently highlighted [22][24], [30], [32], [46]. For the queries of finding relationship of research variables, which are often studied were service quality variables [28], [36], [42], [43], and organizational performance [28], [36], [41].

The issue of public procurement with an environmental perspective and leveraging social welfare has appeared since Presidential Decree 54/2010. Sustainable procurement has been encouraged in PerPres 16/2018 and Perpres 12/2021 mandated. However, we have not found research variables evidence on environmental insight, social responsibility, green industrial products, environmentally friendly products, or sustainable procurement in this public procurement SLR. To be sure, we also expanded the search by reviewing the manuscript of published articles that were excluded in the previous process and searching through Google Scholar. We found several studies on sustainable procurement in Indonesia. The qualitative assessment of the readiness of business entities in the adoption of sustainable procurement by Achmad [47]. Analysis of Indonesia's policy in sustainable public procurement of goods/services by Kamal [48]. And the prospect of sustainable procurement in promoting corporate social responsibility in Indonesia by Marita [49]. The strategic role of sustainable public procurement of goods/services could improve health, the environment, and social life post the COVID-19 pandemic [50]

\section{Conclusions and Recommendations}

Why is there not much evidence of Sustainable Government Goods/Services Procurement research yet? This issue is on the agenda of 
our. future research in Indonesia. What factors hinder and foster the Government's Sustainable Procurement of Goods/Services, and what are the strategies for increasing the extent of Sustainable Goods/Services Procurement. Some common perceptions regarding the implementation of sustainable procurement in Indonesia are needed. It is inevitable to grasp the characteristics of procurement actors regarding the sustainable procurement of goods/services before determining the strategy of sustainable procurement policies.

We re-scoured Google Scholar for manuscripts on sustainable procurement in Indonesia and found a survey on Sustainable Public Procurement in Indonesia conducted by the Government Goods and Services Procurement Policy Institute (LKPP) in 2013 [51]. The survey shows that the main impediment in sustainable procurement was related to the perspective or perception of each party in interpreting the term sustainable procurement. The second hurdle was related to the legality and readiness of management structures, institutional or organizational structures, and equipment infrastructure or supporting technology. The third hurdle was related to the management capacity or human capacity that leads out this sustainable procurement of government goods and services. Some new knowledge and skills must be prevailed by various parties to ensure the essence and objectives of sustainable procurement have in the entire process maintained from time to time. The survey findings with the Systematic Review by Vejaratnam et al., [52], were in line, which five inhibiting subjects originating from finance, legal, people, knowledge, and organization. Lack of knowledge and awareness were the primary barriers to sustainable public procurement.

\section{Appendix A. Reviewed Publication Data}

The systematic literature review workflow corresponding to Figure 1, follows the review protocol in Table 2. Our initial search process found 72 unique articles that we filtered against duplicates. Then, were these articles selected to discard 34 publications of decent quality and only included 38 writings from nationally accredited journals. We then examined each full article and found nine articles that only focused on legal, political, or technical aspects, not directly correlated to our research questions. The selection process gives 29 articles in table A1.

Table A1. The 29 publications meet the criteria for review in this SLR.

\begin{tabular}{|c|c|c|}
\hline No. & Authors & Publication Title \\
\hline 1. & Realize, (2013) [27] & $\begin{array}{l}\text { The Impact of the Electronic Procurement } \\
\text { Service System on the Interests of Prospective } \\
\text { Bussines Entities in Batam }\end{array}$ \\
\hline 2. & $\begin{array}{l}\text { Sofian, Ilat, \& } \\
\text { Wokas, (2013) } \\
{[24]}\end{array}$ & $\begin{array}{l}\text { User Perception on the Application of } \\
\text { Electronic Procurement Auction; Improving } \\
\text { the Quality of Good Governance in the } \\
\text { Ministry of Religion in North Sulawesi }\end{array}$ \\
\hline 3. & $\begin{array}{l}\text { Octorano, (2015) } \\
{[40]}\end{array}$ & $\begin{array}{l}\text { The Rule of Coordination, Competence, and } \\
\text { Discipline on the Performance of Procurement } \\
\text { Service Unit Employees of the National } \\
\text { Ministry of Religion }\end{array}$ \\
\hline 4. & Hidayat, (2015) [25] & $\begin{array}{l}\text { Implementation of E-Procurement in the } \\
\text { Procurement Process of Government Goods } \\
\text { and Services to Support Regional Governance } \\
\text { Resilience (Study on the Procurement Service }\end{array}$ \\
\hline
\end{tabular}

\begin{tabular}{|c|c|c|}
\hline & & $\begin{array}{l}\text { Unit of the Government of North Penajam } \\
\text { Paser Regency, East Kalimantan Province) }\end{array}$ \\
\hline 5. & $\begin{array}{l}\text { Mashuri, (2015) } \\
{[30]}\end{array}$ & $\begin{array}{l}\text { Analysis of Electronic Procurement of Goods } \\
\text { and Services at the Communication and } \\
\text { Information Office of Maros Regency }\end{array}$ \\
\hline 6. & $\begin{array}{l}\text { Darmapramita, } \\
\text { Salain, \& Nadiasa, } \\
\text { (2015) [21] }\end{array}$ & $\begin{array}{l}\text { Analysis of the Maturity Level of the Badung } \\
\text { Regency Procurement Service Unit }\end{array}$ \\
\hline 7. & $\begin{array}{l}\text { Subagyo, Suseno, \& } \\
\text { Ernawati, (2016) } \\
\text { [42] }\end{array}$ & $\begin{array}{l}\text { The Rule of Leadership, Employee Loyalty } \\
\text { and Employee Performance on Service } \\
\text { Quality of the Goods/Services Procurement } \\
\text { Service Unit }\end{array}$ \\
\hline 8. & Talle, (2016) [43] & $\begin{array}{l}\text { The Importance of Motivation on Service } \\
\text { Quality in the Procurement Service Unit of } \\
\text { North Mamuju Regency }\end{array}$ \\
\hline 9. & $\begin{array}{l}\text { Temaluru, Asnawi, } \\
\text { \& Falah, (2016) [39] }\end{array}$ & $\begin{array}{l}\text { The Rule of the Procurement Service Unit on } \\
\text { the Efficiency and Effectiveness of the } \\
\text { Procurement of Goods/Services in the Papua } \\
\text { Provincial Government. }\end{array}$ \\
\hline 10. & $\begin{array}{l}\text { Pratama, (2016) } \\
{[23]}\end{array}$ & $\begin{array}{l}\text { The Importance of Competence, } \\
\text { Communication, and Compensation on the } \\
\text { Performance of Working Groups in the } \\
\text { Procurement Service Unit of the Provincial } \\
\text { Government of East Kalimantan }\end{array}$ \\
\hline 11. & $\begin{array}{l}\text { Mashuri, (2016) } \\
\text { [32] }\end{array}$ & $\begin{array}{l}\text { Transparency Analysis of Electronic } \\
\text { Procurement of Goods and Services at the } \\
\text { Communication and Information Office of } \\
\text { Maros Regency, South Sulawesi Province }\end{array}$ \\
\hline 12. & $\begin{array}{l}\text { Budayasa, Salain, \& } \\
\text { Nadiasa, (2016) [36] }\end{array}$ & $\begin{array}{l}\text { Satisfaction Analysis of Local Government } \\
\text { Work Unit and Business entities on the } \\
\text { Performance of the Procurement Service Unit } \\
\text { of the Badung Regency Government }\end{array}$ \\
\hline 13. & Adi, (2017) [22] & $\begin{array}{l}\text { Analysis of E-Procurement Implementation } \\
\text { Using an Electronic Procurement System: A } \\
\text { Case Study on Electronic Procurement } \\
\text { Services Ministry of Finance, West Papua }\end{array}$ \\
\hline 14. & $\begin{array}{l}\text { Mulyono \& } \\
\text { Setyawan, (2018) } \\
\text { [34] }\end{array}$ & $\begin{array}{l}\text { Effectiveness of Procurement of Goods and } \\
\text { Services by the Implementation of Probity } \\
\text { Advice in Trenggalek Regency }\end{array}$ \\
\hline 15. & $\begin{array}{l}\text { Hulukati \& } \\
\text { Hikmawati, (2018) } \\
\text { [20] }\end{array}$ & $\begin{array}{l}\text { Evaluation of the Implementation of Cobit } 5 \\
\text { in Electronic Procurement Services in } \\
\text { Gorontalo Province }\end{array}$ \\
\hline 16. & $\begin{array}{l}\text { Sudiani, Salain, \& } \\
\text { Dharmayanti, } \\
\text { (2018) [28] }\end{array}$ & $\begin{array}{l}\text { Services Evaluation of Procurement Service } \\
\text { Unit on the Satisfaction Level of Local } \\
\text { Government Work Unit and Goods/Services } \\
\text { Providers in the Denpasar City Government }\end{array}$ \\
\hline 17. & Putri, (2019) [46] & $\begin{array}{l}\text { Transparency in the Implementation of E- } \\
\text { Procurement at the Electronic Procurement } \\
\text { Agency of Padang City }\end{array}$ \\
\hline 18. & $\begin{array}{l}\text { Hamkah, Purwanto, } \\
\& \text { Matitaputty, } \\
\text { (2019) [18] }\end{array}$ & $\begin{array}{l}\text { Evaluation of Bidding Documents by Contract } \\
\text { Type }\end{array}$ \\
\hline 19. & $\begin{array}{l}\text { Vitasari \& Fanida, } \\
\text { (2019) [29] }\end{array}$ & $\begin{array}{l}\text { Implementation of Auction Proposal } \\
\text { Information System Services in the } \\
\text { Goods/Services Procurement Work Unit of } \\
\text { Surabaya City }\end{array}$ \\
\hline 20. & Arifin, (2020) [17] & $\begin{array}{l}\text { Managerial Decision Making: Lease Or Buy } \\
\text { Options in Procurement of Government } \\
\text { Official Vehicles (Case Study at the } \\
\text { Secretariat General of the Ministry of } \\
\text { Finance) }\end{array}$ \\
\hline
\end{tabular}




\begin{tabular}{|c|c|c|}
\hline 21. & $\begin{array}{l}\text { Nani \& Ali, (2020) } \\
\text { [37] }\end{array}$ & $\begin{array}{l}\text { Determinants of Effective E-Procurement } \\
\text { System: Empirical Evidence from Indonesian } \\
\text { Local Governments }\end{array}$ \\
\hline 22. & $\begin{array}{l}\text { Odi \& Suryani, } \\
(2020)[26]\end{array}$ & $\begin{array}{l}\text { Acceptance Analysis of The East Java } \\
\text { Province E-Procurement System Using TAM } \\
\text { Method }\end{array}$ \\
\hline 23. & $\begin{array}{l}\text { Mayasari, (2020) } \\
{[45]}\end{array}$ & $\begin{array}{l}\text { Comparison of Manual Based Auction With } \\
\text { Electronic Procurement Service System }\end{array}$ \\
\hline 24. & $\begin{array}{l}\text { Irsutami, Irianto, \& } \\
\text { Artika, (2020) [33] }\end{array}$ & $\begin{array}{l}\text { Feasibility of Implementing Coso Framework- } \\
\text { Based Internal Control System in Batam State } \\
\text { Polytechnic Procurement Service Unit }\end{array}$ \\
\hline 25. & $\begin{array}{l}\text { Sundari \& Rifai, } \\
(2020)[41]\end{array}$ & $\begin{array}{l}\text { The Significant of Motivation, Competence, } \\
\text { and Providing Incentives on the Performance } \\
\text { of the Decision-maker Working Group } \\
\text { Employees }\end{array}$ \\
\hline 26. & $\begin{array}{l}\text { Mardiana \& Cholil, } \\
(2020) \text { [19] }\end{array}$ & $\begin{array}{l}\text { Analysis of Information Technology Service } \\
\text { Management LPSE Palembang City Based on } \\
\text { ITIL V3 Framework }\end{array}$ \\
\hline 27. & $\begin{array}{l}\text { Dama, Rotinsulu, \& } \\
\text { Walewangko, } \\
\text { (2020) [38] }\end{array}$ & $\begin{array}{l}\text { The Impression of E-purchasing } \\
\text { Implementation, Market Access, and Business } \\
\text { Competitive, on the Principles of Government } \\
\text { Procurement of Goods/Services }\end{array}$ \\
\hline 28. & $\begin{array}{l}\text { Lumintang, } \\
\text { Masinambow, \& } \\
\text { Walewangko, } \\
\text { (2020) [44] }\end{array}$ & $\begin{array}{l}\text { Analysis of the Implementation of E- } \\
\text { Procurement at LPSE of Southeast Minahasa } \\
\text { Regency }\end{array}$ \\
\hline 29. & $\begin{array}{l}\text { Kusuma, (2021) } \\
{[35]}\end{array}$ & $\begin{array}{l}\text { Decision Making on the Procurement of } \\
\text { Goods/Services by the Decision-maker } \\
\text { Working Group at the Depati Bahrin Hospital, } \\
\text { Bangka Regency }\end{array}$ \\
\hline
\end{tabular}

\section{Appendix B. Review Data Extraction}

Table B1. Identification of research variables in the category of investigating variables relationship.

\begin{tabular}{|c|c|c|c|}
\hline No. & Strategic Management & Authors & Tally \\
\hline 1. & Fair, not discriminatory & [27] & 1 \\
\hline 2. & Accountability & [37] & 1 \\
\hline 3. & Physical evidence (Tangible) & {$[28],[36]$} & 2 \\
\hline 4. & Responsiveness & {$[28],[36]$} & 2 \\
\hline 5. & Effectiveness & [37], [34], [27], [39] & 4 \\
\hline 6. & Efficiency & [37], [45], [27], [39] & 4 \\
\hline 7. & Proposal evaluation & {$[32]$} & 1 \\
\hline 8. & Service innovation & {$[35]$} & 1 \\
\hline 9. & $\begin{array}{l}\text { Intervention on Decision-maker } \\
\text { Working Group (Pokja Pemilihan) }\end{array}$ & {$[35]$} & 1 \\
\hline 10. & Assurance & {$[28],[36]$} & 2 \\
\hline 11. & Reliability & {$[28],[36]$} & 2 \\
\hline 12. & $\begin{array}{l}\text { Institutions, Integrity \& Authorities of } \\
\text { ULP }\end{array}$ & [39], [35], [21], [29] & 4 \\
\hline 13. & Empathy & {$[28],[36]$} & 2 \\
\hline 14. & User satisfaction & {$[27],[28],[36]$} & 3 \\
\hline 15. & $\begin{array}{l}\text { Collaboration between procurements } \\
\text { parties }\end{array}$ & {$[21]$} & 1 \\
\hline 16. & Stakeholder commitment & [35] & 1 \\
\hline
\end{tabular}

\begin{tabular}{|c|c|c|c|}
\hline 17. & Coordination between parties & [35], [21], [40] & 3 \\
\hline 18. & Auction winner criterion & [32] & 1 \\
\hline 19. & Expert qualification & [35] & 1 \\
\hline 20. & Service quality & [42], [43], [27], [36] & 4 \\
\hline 21. & $\begin{array}{l}\text { Performance management in } \\
\text { procurement }\end{array}$ & [21] & 1 \\
\hline 22. & Procurement risk management & [21] & 1 \\
\hline 23. & Maturity & [19], [21] & 2 \\
\hline 24. & User interest & [27] & 1 \\
\hline 25. & $\begin{array}{l}\text { Monitoring and evaluation of } \\
\text { information technology performance }\end{array}$ & [20] & 1 \\
\hline 26. & $\begin{array}{l}\text { Internal control monitoring and } \\
\text { evaluation }\end{array}$ & [20] & 1 \\
\hline 27. & Integrity pact in procurement & [21] & 1 \\
\hline 28. & $\begin{array}{l}\text { Implementation and control of } \\
\text { procurement }\end{array}$ & [21] & 1 \\
\hline 29. & $\begin{array}{l}\text { Use of Information Technology in } \\
\text { procurement }\end{array}$ & [21] & 1 \\
\hline 30. & Market competition & {$[27],[38]$} & 2 \\
\hline 31. & supply chain & [35] & 1 \\
\hline 32. & IT facilities and infrastructure & [21] & 1 \\
\hline 33. & Procurement strategy and planning & [21] & 1 \\
\hline 34. & Management of the e-procurement & {$[45],[35],[20]$} & 3 \\
\hline 35. & Procurement transparency & [37], [46], [27], [32] & 4 \\
\hline No. & HR Management & Authors & Tally \\
\hline 1. & Incentive & {$[41],[23],[21]$} & 3 \\
\hline 2. & Staff cadre & [21] & 1 \\
\hline 3. & Self-actualization needs & [43] & 1 \\
\hline 4. & Physiological needs & [43] & 1 \\
\hline 5. & Appreciation needs & [43] & 1 \\
\hline 6. & Need for security & [43] & 1 \\
\hline 7. & Social needs & [43] & 1 \\
\hline 8. & Leadership & {$[42],[21]$} & 2 \\
\hline 9. & Teamwork & [35] & 1 \\
\hline 10. & Staff availability & {$[35],[21]$} & 2 \\
\hline 11. & Performance of employee & [40] & 2 \\
\hline 12. & Working group performance & [41], [23], [21], [36] & 4 \\
\hline 13. & Staff proficiency & $\begin{array}{l}{[40],[41],[23],} \\
{[35],[21]}\end{array}$ & 5 \\
\hline 14. & Communication & {$[23],[32],[29]$} & 3 \\
\hline 15. & Work environment & [37] & 1 \\
\hline 16. & Staff loyalty & [42] & 1 \\
\hline 17. & Motivation & [43], [41] & 2 \\
\hline 18. & Technical training and education & [21] & 1 \\
\hline 19. & ULP staff member planning & [21] & 1 \\
\hline 20. & Staff career plan & [21] & 1 \\
\hline 21. & Mental attitude & [32], [29] & 2 \\
\hline
\end{tabular}




\begin{tabular}{|c|c|c|c|}
\hline No. & Financial Management & Authors & Tally \\
\hline 1. & Goods Expenditure & [44] & 1 \\
\hline 2. & Construction Cost & [44] & 1 \\
\hline 3. & Consulting Cost & [44] & 1 \\
\hline 4. & Direct Expenditure & [44] & 1 \\
\hline 5. & Fuel Cost & [17] & 1 \\
\hline 6. & Vehicle Overhaul Cost & [17] & 1 \\
\hline 7. & Vehicle Tax & [17] & 1 \\
\hline 8. & Vehicle Procuring & [17] & 1 \\
\hline 9. & Maintenance and Operational Cost & [17] & 1 \\
\hline 10. & State Property Write-off & [17] & 1 \\
\hline 11. & Vehicle Rental Fee & [17] & 1 \\
\hline 12. & Operational reserves & [35] & 1 \\
\hline 13. & Budget efficiency and effectiveness & [39] & 1 \\
\hline 14. & Owner Estimate & {$[18]$} & 1 \\
\hline 15. & Unit Price Contract & {$[18]$} & 1 \\
\hline 16. & Lump-Sum Contract & {$[18]$} & 1 \\
\hline 17. & Net Present Value & [17] & 1 \\
\hline 18. & Residual Value & [17] & 1 \\
\hline 19. & Opportunity Cost & [17] & 1 \\
\hline 20. & $\begin{array}{l}\text { Accountable principle of Government } \\
\text { Procurement of Goods/Services }\end{array}$ & [38] & 1 \\
\hline 21. & Budget Estimate Plan Offer & {$[18]$} & 1 \\
\hline 22. & Sunk Cost & [17] & 1 \\
\hline 23. & Total Cost of Ownership & [17] & 1 \\
\hline No. & Information Management & Authors & Tally \\
\hline 1. & Access Management & [19] & 1 \\
\hline 2. & Control activities & [33] & 1 \\
\hline 3. & Control environment & [33] & 1 \\
\hline 4. & Event Management & [19] & 1 \\
\hline 5. & Hardware & [29] & 1 \\
\hline 6. & e-Purchasing implementation & [38] & 1 \\
\hline 7. & Incident Management & [19] & 1 \\
\hline 8. & Information and communication & [33] & 1 \\
\hline 9. & Information Security Management & [19] & 1 \\
\hline 10. & Information quality & [27] & 1 \\
\hline 11. & System quality & [27] & 1 \\
\hline 12. & Monitoring & {$[33]$} & 1 \\
\hline 13. & Request Fullfilment & [19] & 1 \\
\hline 14. & Risk assessment & {$[33]$} & 1 \\
\hline 15. & Software & [29] & 1 \\
\hline
\end{tabular}

Table B2. Identification of research methods.

\begin{tabular}{llll}
\hline No. & Research Approach & Authors & Tally \\
\hline 1. & descriptive analysis & {$[22]$} & 1 \\
\hline
\end{tabular}

\begin{tabular}{|c|c|c|c|}
\hline 2. & associative & {$[38]$} & 1 \\
\hline 3. & descriptive & $\begin{array}{l}\text { [40], [25], [43], } \\
{[46],[35],[21],} \\
\text { [44], [29] }\end{array}$ & 8 \\
\hline 4. & explorative & [34] & 1 \\
\hline 5. & ethnography & [24] & 1 \\
\hline 6. & qualitative & $\begin{array}{l}{[22],[30],[34],} \\
{[46],[24],[35],} \\
{[32],[29]}\end{array}$ & 8 \\
\hline 7. & quantitative & [43], [44] & 2 \\
\hline 8. & quantitative and qualitative & [25] & 1 \\
\hline 9. & verification & [40], [27], [29] & 3 \\
\hline No. & Data Collection & Authors & Tally \\
\hline 1. & documentation & [30], [34], [24], [32] & 4 \\
\hline 2. & questionnaire & $\begin{array}{l}\text { [37], [22], [25], } \\
{[42],[39],[28]}\end{array}$ & 6 \\
\hline 3. & Miles and Huberman method & [17] & 1 \\
\hline 4. & observation & $\begin{array}{l}{[25],[30],[34],} \\
{[24],[32]}\end{array}$ & 5 \\
\hline 5. & triangulation & [31], [35] & 2 \\
\hline 6. & Interview & $\begin{array}{l}{[17],[22],[25],} \\
{[30],[34],[24],} \\
{[35],[32]}\end{array}$ & 8 \\
\hline No. & Data Analysis & Authors & Tally \\
\hline 1. & coefficient of determination analysis & {$[40]$} & 1 \\
\hline 2. & difference analysis & [18] & 1 \\
\hline 3. & the Benefit to Cost Ratio & [17] & 1 \\
\hline 4. & COBIT 5 & [20] & 1 \\
\hline 5. & Coso framework & [33] & 1 \\
\hline 6. & $\begin{array}{l}\text { Indonesia Procurement Maturity } \\
\text { Model (IPM2) }\end{array}$ & [21] & 1 \\
\hline 7. & ITIL V3 & [19] & 1 \\
\hline 8. & net present value & [17] & 1 \\
\hline 9. & Partial Least Square & [37] & 1 \\
\hline 10. & conclusion withdraw & [30], [29] & 2 \\
\hline 11. & data presentation & [30], [35], [29] & 3 \\
\hline 12. & data reduction & [30], [35], [29] & 3 \\
\hline 13. & linear regression & $\begin{array}{l}{[40],[42],[43],} \\
{[41],[27],[39],} \\
{[28],[44]}\end{array}$ & 8 \\
\hline 14. & service quality & {$[28],[36]$} & 2 \\
\hline 15. & total cost of ownership & [17] & 1 \\
\hline
\end{tabular}

\section{REFERENCES}

[1] G. H. Brundtland, M. Khalid, and E. Salim, Our Common Future. Oxford: World Commision on Environment and Development, 1987. https://doi.org/ 10.1080/07488008808408783

[2] J. D. Sachs, "From millennium development goals to sustainable 
development goals," Lancet, vol. 379, no. 9832, pp. 2206-2211, 2012. https://doi.org/10.1016/S0140-6736(12)60685-0

[3] S. Panuluh and M. R. Fitri, "Perkembangan Pelaksanaan Sustainable Development Goals (SDGs) di Indoneisa: September 2015-September 2016," 2016.

[4] W. Stiawan, "ULP dan LPSE, Pilar Utama Reformasi Pengadaan Barang/Jasa Pemerintah," Warta e-Procurement, Jakrta, pp. 5-8, 2012.

[5] LKPP, Norma Standar Prosedur Manual Model Kematangan UKPBJ. Lembaga Kebijakan Pengadaan Barang/Jasa Pemerintah, 2019.

[6] A. Kuckertz and J. Block, "Reviewing systematic literature reviews: ten key questions and criteria for reviewers," Manag. Rev. Q., vol. 71, no. 3, pp. 519-524, 2021.

[7] W. R. Clark, L. A. Clark, D. M. Raffo, and R. I. Williams, "Extending Fisch and Block's (2018) tips for a systematic review in management and business literature," Manag. Rev. Q., vol. 71, no. 1, pp. 215-231, 2021. https://doi.org/10.1007/s11301-02000184-8

[8] D. Tranfield, D. Denyer, and P. Smart, "Towards a Methodology for Developing Evidence-Informed Management Knowledge by Means of Systematic Review,” Br. J. Manag., vol. 14, pp. 207222, 2003. https://doi.org/10.1111/1467-8551.00375

[9] S. Sepúlveda and A. Cravero, "Protocol adaptations to conduct systematic literature reviews in software engineering: A chronological study," Ing. e Investig., vol. 35, no. 3, pp. 84-91, 2015.

[10] A. M. T. Thomé, L. F. Scavarda, and A. J. Scavarda, "Conducting systematic literature review in operations management," Prod. Plan. Control, vol. 27, no. 5, pp. 408-420, 2016.

[11] R. I. Williams, L. A. Clark, W. R. Clark, and D. M. Raffo, "Reexamining systematic literature review in management research: Additional benefits and execution protocols," Eur. Manag. J., vol. 39, no. 4, pp. 521-533, 2021.

[12] I. Enang, D. Asenova, and S. J. Bailey, "Identifying influencing factors of sustainable public service transformation: a systematic literature review," Int. Rev. Adm. Sci., 2020.

[13] C. Boon, D. N. Den Hartog, and D. P. Lepak, "A Systematic Review of Human Resource Management Systems and Their Measurement," J. Manage., vol. 45, no. 6, pp. 2498-2537, 2019. https://doi.org/10.1177/0149206318818718

[14] I. Mohungoo, I. Brown, and S. Kabanda, "A Systematic Review of Implementation Challenges in Public E-Procurement," in Responsible Design, Implementation and Use of Information and Communication Technology. I3E 2020, 2020, vol. 12067 LNCS, pp. 46-58.

[15] B. Kitchenham, Procedures for Performing Systematic Reviews. Newcastle, UK: Keele University, 2004.

[16] B. Kitchenham and C. Ebse, "Guidelines for performing Systematic Literature Reviews in Software Engineering Executive summary," 2007.

[17] Z. Arifin, "Pengambilan Keputusan Manajerial: Opsi Sewa Atau
Beli Dalam Pengadaan Kendaraan Dinas (Studi Kasus Pada Sekretariat Jenderal Kementerian Keuangan)," $J$. Perbendaharaan, Keuang. Negara dan Kebijak. Publik, vol. 5, no. 1, pp. 217-234, 2020.

[18] Hamkah, H. Purwanto, and J. R. Matitaputty, "Evaluasi Dokumen Penawaran Menurut Jenis Kontrak," J. Simetrik, vol. 9, no. 2, pp. 208-214, 2019.

[19] D. Mardiana and W. Cholil, "Analisis Information Technology Service Management (ITSM) LPSE Kota Palembang Berdasarkan Framework ITIL V3," J. Intelekt. Keislaman, Sos. dan Sains, vol. 9, no. 1, pp. 1-8, 2020.

[20] S. A. Hulukati and N. K. Hikmawati, "Evaluasi Penerapan Cobit 5 Pada Layanan Pengadaan Secara Elektronik (LPSE) Di Provinsi Gorontalo," METIK J., vol. 2, no. 1, pp. 40-45, 2018.

[21] I. G. U. Darmapramita, I. M. A. K. Salain, and M. Nadiasa, “Analisis Tingkat Kematangan (Maturity Levels) Unit Layanan Pengadaan Kabupaten Badung," J. Spektran, vol. 3, no. 2, pp. 3140, 2015.

[22] C. S. W. Adi, “Analisis Penerapan E-procurement Menggunakan Sistem Pengadaan Secara Elektronik: Studi Kasus Pada Layanan Pengadaan Secara Elektronik (LPSE) Kementerian Keuangan Papua Barat," Indones. Treas. Rev. J. Perbendaharaan, Keuang. Negara, dan Kebijak. Publik, vol. 2, no. 2, pp. 1-16, 2017.

[23] H. Pratama, "Pengaruh Kompetensi, Komunikasi Dan Kompensasi Terhadap Kinerja Kelompok Kerja Pada Unit Layanan Pengadaan Pemerintah Provinsi Kalimantan Timur," $J$. Paradig., vol. 5, no. 2, pp. 79-94, 2016.

[24] S. Sofian, V. Ilat, and H. Wokas, "Persepsi Pengguna Pada Penerapan Lelang Pengadaan Secara Elektronik (LPSE) Salah Satu Wujud Peningkatan Kualitas Good Governance Di Kementerian Agama Se Sulawesi Utara," J. Ris. Akunt. dan Audit. Magister Akunt. Fak. Ekon. dan Bisnis Unsrat, vol. 4, no. 2, pp. 37-73, 2013.

[25] R. Hidayat, "Penerapan E-procurement Dalam Proses Pengadaan Barang Dan Jasa Pemerintah Guna Mendukung Ketahanan Tata Pemerintahan Daerah (Studi Pada Unit Layanan Pengadaan Barang Dan Jasa Pemerintah Kabupaten Penajam Paser Utara Provinsi Kalimantan Timur),” J. Ketahanan Nas., vol. 21, no. 2, p. 118, 2015.

[26] M. Odi and E. Suryani, "Acceptance Analysis of The East Java Province E-Procurement System Using TAM Method," IPTEK J. Technol. Sci., vol. 31, no. 2, p. 127, 2020.

[27] Realize, "Pengaruh Penggunaan Sistem Layanan Pengadaan Secara Elektronik (LPSE) Terhadap Minat Calon Penyedia Di Batam," Comput. Based Inf. Syst. J., vol. 1, no. 2, 2013.

[28] N. K. Sudiani, I. M. A. K. Salain, and G. A. P. C. Dharmayanti, "Evaluasi Pelayanan Unit Layanan Pengadaan (ULP) Terhadap Tingkat Kepasan Satuan Kerja Perangkat Daerah (SKPD) Dan Penyedia Barang/Jasa Di Lingkungan Pemerintah Kota Denpasar," J. Spektran, vol. 6, no. 2, pp. 217-223, 2018.

[29] V. N. Vitasari and E. H. Fanida, "Implementasi Layanan Sistem Informasi Usulan Lelang (SIUL) Di Unit Kerja Pengadaan 
Barang/Jasa (UKPBJ) Kota Surabaya,” Publika, vol. 7, no. 1, pp. $1-8,2019$.

[30] M. A. Mashuri, “Analisis Layanan Pengadaan Barang Dan Jasa Secara Elektronik (Lpse) Pada Kantor Komunikasi Dan Informasi Kabupaten Maros," J. Natapraja Kaji. Ilmu Adm. Negara, vol. 3, no. 2, pp. 67-83, 2015.

[31] T. D. Putri, "Transparansi Dalam Pelaksanaan E-procurement Pada Lembaga Pengadaan Secara Elektronik (LPSE) Kota Padang," Menara Ilmu, vol. XIII, no. 11, pp. 103-109, 2019.

[32] M. A. Mashuri, "Analisis Transparansi Layanan Pengadaan Barang Dan Jasa Secara Elektronik (Lpse) Pada Kantor Komunikasi Dan Informasi Kabupaten Maros Provinsi Sulawesi Selatan,” J. Din. Gov., vol. 6, no. 1, pp. 13-22, 2016.

[33] Irsutami, D. Irianto, and J. Artika, "Kemungkinan Implementas Sistem Pengendalian Internal Berbasis Coso Framework Pada Unit Layanan Pengadaan Politeknik Negeri Batam,” J. Appl. Manag. Account., vol. 4, no. 1, pp. 70-93, 2020.

[34] J. Mulyono and D. Setyawan, "Efektivitas Pengadaan Barang Dan Jasa Melalui Penerapan Probity Advice Di Kabupaten Trenggalek Joko,” J. Reformasi, vol. 8, no. 2, pp. 198-212, 2018.

[35] T. P. . Kusuma, "Pelaksanaan Pemilihan Pengadaan Barang/Jasa oleh Kelompok Kerja Pemilihan pada RSUD Depati Bahrin Kabupaten Bangka," J. Ilm. STIKES Citra Delima Bangka Belitung, vol. 4, no. 2, pp. 1-11, 2021.

[36] P. Budayasa, I. M. A. K. Salain, and M. Nadiasa, "Analisis Kepuasan Satuan Kerja Perangkat Daerah (SKPD) Dan Rekanan Terhadap Kinerja Unit Layanan Pengadaan (ULP) Pemerintah Kabupaten Badung,”J. Spektran, vol. 4, no. 1, pp. 28-36, 2016.

[37] D. A. Nani and S. Ali, "Determinants of Effective E-Procurement System: Empirical Evidence from Indonesian Local Governments," J. Din. Akunt. dan Bisnis, vol. 7, no. 1, pp. 3350, 2020.

[38] Y. Dama, T. O. Rotinsulu, and E. N. Walewangko, "Pengaruh Implementasi E-purchasing, Akses Pasar, Dan Persaingan Bisnis Terhadap Prinsip Akuntabel Pengadaan Barang/jasa Pemerintah," J. Pembang. Ekon. dan Keuang. Drh., vol. 21, no. 3, pp. 39-53, 2020.

[39] N. A. R. Temaluru, M. Asnawi, and S. Falah, "Pengaruh penerapan unit layanan pengadaan (ULP) terhadap efisiensi dan efektifitas pengadaan barang atau jasa pada pemerintah propinsi Papua.," KEUDA (Jurnal Kaji. Ekon. dan Keuang. Daerah), vol. I, no. I, pp. 127-151, 2016.

[40] D. F. Octorano, "Pengaruh Koordinasi, Kompetensi Dan Disiplin Terhadap Kinerja Pegawai Unit Layanan Pengadaan Kementerian Agama Pusat (ULP Kemenag Pusat)," J. Mix, vol. 5, no. 1, pp. 10-17, 2015.

[41] S. Sundari and A. Z. Rifai, "Dampak Motivasi, Kompetensi, Dan Pemberian Insentif Terhadap Kinerja Pegawai Kelompok Kerja Pemilihan," J. Adm. Kant., vol. 8, no. 2, pp. 199-208, 2020.

[42] M. Subagyo, D. Suseno, and Ernawati, "Pengaruh Kepemimpinan, Loyalitas Karyawan Dan Kinerja Karyawan Terhadap Kualitas Pelayanan Unit Layanan Pengadaan
Barang/jasa," J. Manaj. Sumber Daya Mns., vol. 10, no. 1, pp. 87-94, 2016.

[43] A. Talle, "Pengaruh Motivasi Terhadap Kualitas Pelayanan Pada Unit Layanan Pengadaan Kabupaten Mamuju Utara," $J$. Katalogis, vol. 4, no. 4, pp. 201-210, 2016.

[44] M. N. Lumintang, V. A. J. Masinambow, and E. N. Walewangko, "Analisis Pelaksanaan Pengadaan Barang Dan Jasa Secara Elektronik (E-Procurement) Di Lpse Kabupaten Minahasa Tenggara," J. Pembanguan Ekon. dan Keuang. Drh., vol. 21, no. 1, pp. 105-121, 2020.

[45] V. Mayasari, "Perbandingan Pelelangan Berbasis Sistem Manual Dengan Sistem Layanan Pengadaan Secara Elektronik (Lpse)," Konstruksia, vol. 11, no. 1, p. 79, 2020.

[46] T. D. Putri, "Transparansi dalam Pelaksanaan e-Procurement pada Lembaga Pengadaan Secara Elektronik (LPSE) Kota Padang," Menara Ilmu, vol. 13, no. 11, pp. 103-109, 2019.

[47] Y. A. Achmad, "Kesiapan Para Penyedia Terhadap Kebijakan Pengadaan Barang Atau Jasa Berkelanjutan (Sustainable Public Procurement)," Ug J., vol. 14, no. 12, pp. 32-42, 2020.

[48] M. Kamal, "Analisis Kebijakan Pengadaan Barang Dan Jasa Pemerintah Berkelanjutan," J. Transform. Adm., vol. 10, no. 02, pp. 131-142, 2021.

[49] L. Marita, M. B. Munir, N. Andriani, and M. Syarif, "Bagaimana Pengadaan Barang / Jasa Pemerintah Berkelanjutan dapat Mendorong Tanggung-Jawab Sosial Perusahaan di Indonesia?," in Seminar Nasional Manajemen dan Call for Paper (SENIMA 6), 2021, pp. 311-319. Retrieved from http://senima.conference.unesa.ac.id/ocs/index.php/senima2018/ SenimaUnesa6/paper/view/547/344

[50] L. Marita, "Sinergi Pelaku Pengadaan Publik Berkelanjutan Pasca Covid-19 | TIMES Indonesia," Times Indonesia, 19-Sep2021.

https://www.timesindonesia.co.id/read/news/371105/sinergipelaku-pengadaan-publik-berkelanjutan-pasca-covid19

[51] Subdirektorat Iklim Usaha, Direktorat Pengembangan Iklim Usaha dan Kerjasama Internasional, and Lembaga Kebijakan Pengadaan Barang dan Jasa Pemerintah, "Sustainable Public Procurement," J. Pengadaan, vol. 3, no. 3, pp. 13-48, 2013. Retrieved from http://www.lkpp.go.id/v3/\#/read/2318

[52] N. Vejaratnam, Z. F. Mohamad, and S. Chenayah, "A systematic review of barriers impeding the implementation of government green procurement," J. Public Procure., vol. 20, no. 4, pp. 451$471,2020$. 